\title{
Organizational Leadership Management Through Pancasila Values in Character Building
}

\author{
Farid Wajdi \\ Faculty of Teacher Training and Education, Universitas Sembilanbelas November Kolaka, Indonesia \\ *Corresponding author. Email: wajdikf83@usn.ac.id
}

\begin{abstract}
The purpose of this study is to describe the management of organizational leadership through the values of Pancasila in character building in students of the Pancasila and Citizenship Education study program for the 2020 academic year USN Kolaka, which participates in the student association as its organization. The reason is, the young generation as the nation's successor is a baton in managing and advancing human resources in a country. The Indonesian state has a national ideology, namely Pancasila as the state philosophy. The era of disruption and pandemic is an example of the challenges that must be faced by the nation. The school (campus) is a forum for managing, shaping, and actualizing student personalities in character building. The type of research used is descriptive qualitative by applying observation, documentation, and interview techniques. Data analysis techniques are carried out by categorizing and grouping based on logical analysis, then interpreted in the context of the research problem as a whole. The results showed that students through basic leadership training still lacked an applicative understanding of management, leadership, and organization, this can be seen from an incomplete understanding of organizational management. This research is expected that students will be able to manage organizations as character building through the values of Pancasila as the philosophy and ideology of the Indonesian nation in order to be able to face the challenges of globalization and pandemics that still haunt human life.
\end{abstract}

Keywords: Character Building, Organizational Leadership Management, Pancasila Values.

\section{INTRODUCTION}

Humans are God's creatures who are given the responsibility of managing and managing the natural world. Over time, humans who lead the world have made regulations in their territory as the identity of the country they have. All countries in the world, without exception, the unitary republic of Indonesia before and after the formation of the unitary state already has a national identity, namely Pancasila as the ideology and philosophy of national life. To maintain and always the Indonesian people united, until now the nation's founders have always tried to revive the values of Pancasila in every element of the nation's life including in educational units ranging from basic education to higher education (college).

Pancasila and citizenship education is one of the subject matter in the character-building process which is developed through the educational process so that it affects social life. Character building through Pancasila values that are carried out in higher education, one of which is with the activities of the Pancasila and citizenship education study program student association
(HMPS) as education in shaping the personality of students. Education as a management tool in shaping the development of the human person plays an important role in dealing with situations and conditions of life [1].

A collection of individual youths in a forum is the first step in the foundation of the strength of the nation's children in expressing ideas in order to gain knowledge, education, and experience to find answers to challenges and overcome the problems they face. The collective spirit of the youth who become members of youth organizations is a major force pushing Indonesia into an independent, sovereign, and state equal with other nations around the world [2]. The need to strengthen the noble values of the nation as the nation and state's foundation can be filled through education [3]. With this activity, it is hoped that students will be able to become organizational leaders in managing their members in facing life and challenges in the future as social interaction with a society that has a diversity of cultures, religions, and languages.

Entering the era of disruption, globalization, development, and progress, human resources who have 
the ability to lead are urgently needed along with the value of character education in accordance with the values of the nation's character as a national identity. Globalization results in a shift in socio-cultural values that cause a crisis of a nation's identity and impact on the degradation of the character of its citizens [4]. Rapid globalization is a major cause of the deterioration of nationalism [5]. The essence of character education in the perspective of Indonesian education is value education, which is the result of the process of culturing the education of noble values which is reflected in the culture of the Indonesian people in order to form quality Indonesian human resources [6].

Based on this description, the challenges faced in human life will always overshadow the journey of his life. Challenges in the form of competition from various aspects of life in maintaining the dignity of the nation as well as the pandemic that hit the world today, the need for individual youth as human resources who must be prepared to become future humans who are ready to face challenges and answer problems by looking at experiences and living conditions which in the world. Thus, what steps are needed for youth in maintaining national identity when becoming a leader or a member in managing an organization as a place to gain knowledge and through education by instilling Pancasila values as character building for each individual.

\section{THEORETICAL REVIEW}

\section{A. Leadership}

Leadership is an activity that is needed in human life as a social being, because social life requires leaders and leadership. With leadership, you can determine the desired direction or goals and how these directions or goals can be achieved. Leadership is a role term for an individual who has responsibility for a group (community) in managing and directing the goals to be achieved. Leadership is the ability to influence a group to achieve certain goals [7]. Leadership is a social process, in which there are interactions that influence one another [8]. Northouse focuses on the concept of leadership only on four important components, namely a) influence; b) process; c) community; and d) common goals [9]. Leadership can be the key to success in optimizing the management of public services. Leadership is a behavior pattern of leaders in directing and controlling subordinates to follow their will in achieving predetermined goals and objectives, it can be said that leadership is a method used by a leader in influencing his subordinates. Based on this description, leadership is a leader's behavioral activity in providing direction, guidance, influence, contribution, and motivation to the people (individuals) they lead in an organization in order to achieve collective goals (objectives).

\section{B. Organizational Management}

Leadership has a very important role in managing the organization because leadership is in control of every activity, hence the need for knowledge in managing the organization. Etymologically, management comes from English, namely manage means to regulate, in Italian, namely maneggiare means controlling, in French, namely management which is the result of the adoption of English which means managing. And in Indonesian, namely menej has the meaning of regulating, managing (controlling). In terminology, management is a process (activity) of efforts to achieve certain goals through cooperation. In general, the word management means a process consisting of a series of activities, planning, organizing, mobilizing, controlling (supervising) carried out to achieve certain goals set through the use of human resources (HR) and other resources. "Management is cooperation with people to achieve organizational goals by carrying out the functions of planning, organizing, organizing personnel or staffing, direction and leadership, and supervision.

According to Syamsuddin, management is a series of activities in which there are different processes, namely planning, organizing, driving, and controlling so that they can utilize existing resources to achieve goals effectively and efficiently [10]. Management as a process of activity between human resources and raw materials in achieving goals effectively and efficiently which involves an organizational forum, direction of the leadership of the organization, coordination of leaders with organizational members, and evaluation of elements of society. Thus, the essence of management will be able to achieve a goal that is effective and efficient in organizing. According to Ambarwati, organization is a place or place where people gather in a systematic, directed, constrained, planned, rational manner in utilizing all resources both methods, materials, environment, and money as well as facilities and infrastructure and others that are used efficiently. and effective to achieve goals. organization goals [11]. Organization as a forum for human associations in achieving a goal has benefits which are of course good and positive value, among the benefits of organization, namely the ability to communicate, goals achieved, motivation to generate a spirit of leadership, broadminded, have ideas to find solutions to problems, wide social network, able to manage time, mentally strong, and take responsibility.

Based on the description, management is a human activity carried out jointly in achieving a goal through the stages of planning, managing, organizing, directing, controlling, and supervising human resources. Meanwhile, an organization is an activity carried out by a group of people in carrying out work together in a systematic, planned, and guided manner in a forum in order to achieve the desired, effective, and efficient goals. 


\section{METHOD}

This research was conducted on USN Kolaka students in the Pancasila and citizenship education class 2020 study program. The types of data are primary data and secondary data. While the data collection technique was done by interview and document analysis. The research subjects were students of the 2020 Pancasila and citizenship education study program which consisted of 14 (fourteen) students. This research uses descriptive qualitative type by applying observation, documentation, and interview techniques. The data analysis technique is done by categorizing and classifying based on the logical analysis, then interpreted in the context of the whole research problem. then interpreted in the context of the overall research problem. The qualitative research

Table 1. Leadership activities

\begin{tabular}{|c|c|c|c|}
\hline $\begin{array}{l}\text { Participant's } \\
\text { Name }\end{array}$ & Leadership Knowledge & Pancasila values & Understand \\
\hline IGS & \multirow{14}{*}{$\begin{array}{l}\text { - Able to motivate } \\
\text { - Able to speak and communicate with } \\
\text { the crowd } \\
\text { - Able to answer and provide solutions to } \\
\text { problems that arise } \\
\text { - Recognize characteristics of the } \\
\text { members } \\
\text { - The desire to know developments } \\
\text { - The desire to make changes or } \\
\text { improvements. } \\
\text { - Integrity } \\
\text { - Be an example }\end{array}$} & \multirow{14}{*}{$\begin{array}{l}\text { - Believe in the one supreme God } \\
\text { - Justice and civilized humanity } \\
\text { - The unity of Indonesia } \\
\text { - The democracy led by understanding } \\
\text { among honorable representatives } \\
\text { from the parliament house } \\
\text { - Social justice for all of the people of } \\
\text { Indonesia }\end{array}$} & Not Yet \\
\hline RU & & & Yes \\
\hline BPW & & & Not Yet \\
\hline DS & & & Not Yet \\
\hline IR & & & Yes \\
\hline KP & & & Yes \\
\hline LY & & & Not Yet \\
\hline MA & & & Not Yet \\
\hline ME & & & Not Yet \\
\hline $\mathrm{PH}$ & & & Not Yet \\
\hline ANP & & & Yes \\
\hline FR & & & Not Yet \\
\hline SNA & & & Not Yet \\
\hline SN & & & Not Yet \\
\hline
\end{tabular}

Source: result of the analysis of documents, interviews, and observation.
Based on the results of research on basic understanding of leadership, it shows that there are 4 (four) people who understand and 10 (ten) people still lack understanding of leadership. Thus, students are expected to understand more about this if there are student organization activities that are carried out every time there is a moment that directs them about organizational leadership management. method is a method based on the philosophy of positivism.

\section{RESULT AND DISCUSSION}

The results of research on organizational leadership management through Pancasila values in character building in students of the 2020 class Pancasila and citizenship education study program can be explained as follows.

\section{A. Basic Leadership Training}

Students of class 2020 in leadership training are equipped with knowledge about leadership material in student activities in the Pancasila and citizenship education study program. The following is a table of the results of understanding the material that has been given.

\section{B. Organizational Management}

Besides being given an understanding of the basics of leadership, the students were also directed on how to manage a good organization. Of course, this is related to the values of Pancasila as the ideology and philosophy of life of the nation, so that the individual character of students is formed. So that he is able to manage himself to be a leader in organizational activities both macro and micro. The results of research providing material on organizational management are described in the following table. 
Table 2. Organizational management

\begin{tabular}{|c|c|c|c|}
\hline $\begin{array}{l}\text { Participant's } \\
\text { Name }\end{array}$ & Organization Basics & Management Basics & Understand \\
\hline IGS & \multirow{14}{*}{$\begin{array}{l}\text { - Have clear goals } \\
\text { - Delegation of duties and authorities } \\
\text { - Has a structure that encourages } \\
\text { creativity } \\
\text { - Has a single unit of command } \\
\text { - Clear division of tasks }\end{array}$} & \multirow{14}{*}{$\begin{array}{l}\text { - Planning } \\
\text { - Organizing } \\
\text { - Leading } \\
\text { - Controlling } \\
\text { - Motivation }\end{array}$} & Not Yet \\
\hline $\mathrm{RU}$ & & & Yes \\
\hline BPW & & & Not Yet \\
\hline DS & & & Not Yet \\
\hline IR & & & Yes \\
\hline KP & & & Not Yet \\
\hline LY & & & Not Yet \\
\hline MA & & & Not Yet \\
\hline ME & & & Not Yet \\
\hline $\mathrm{PH}$ & & & Not Yet \\
\hline ANP & & & Not Yet \\
\hline FR & & & Not Yet \\
\hline SNA & & & Not Yet \\
\hline SN & & & Not Yet \\
\hline
\end{tabular}

Source: result of the analysis of documents, interviews, and observation.

Based on the results of research on understanding the basics of organizational management, it is known that there are 2 (two) people who understand and 12 (twelve) people who still do not understand organizational management. Thus students are expected to understand more about this if there are student organization activities that are carried out directly or indirectly whenever there is a moment that directs them about the management of organizational leadership.

The results showed that in addition to being given a theoretical understanding of organizational leadership management, students also needed real implementation of student activities held at certain moments as well as humanitarian activities that could have an impact on each individual. Of course, this will show the development of the formation of character values that are in line with the values of Pancasila as a national character which is a national identity. Philosophically, the sublime value of a nation's culture to be one of the basic sources of the country's Pancasila Indonesia [12]. In anticipating global developments, many countries are strengthening civic education [13]. Civic education is one field of study in the national education context which has a strategic role for nation and character building in the midst of Indonesian society heterogeneity [14].

Character building as steps and efforts in the process of personal formation of learners in a nation is based on moral values contained in cultural values, religious values, and the value of the nation. Thus, Pancasila values are a crystallization of cultural values and the religion of the Indonesian people to become a reference for strengthening the country's character-building
Multicultural Indonesia is the goal and function of national education [15]. National Education serves to develop the ability and form the character and civilization of a dignified nation in order to educate the nation's life [16]. Education as the key to success and human progress in facing life's challenges and overcoming problems is the most important thing that humans must go through, because education is a process of coaching, developing, and being able to direct humans to the path of goodness [17]. As a student in the Pancasila and Citizenship education program, they must be able to implement and uphold national values, namely Pancasila. According to the author, every individual as an Indonesian citizen must have and strengthen national identity by strengthening character values through Pancasila values which are the national identity of the Indonesian state. With the existence of organizational leadership management education in the educational unit environment in higher education is an effort to strengthen character education. Ideal values in Pancasila especially concern and responsibility to the values that must be embedded by every young Indonesian citizen in the digital era should be emphasized [18].

Organizational leadership management is one of the places to form and develop the individual character of the nation's children, one of which is by maintaining national unity and integrity as stated in the Pancasila values, namely the unity of Indonesia. To avoid the decline of nationalism among the younger generation as the foundation of the future nation, the values of Pancasila must always be equipped to strengthen the character of the nation. This study provided some guidelines to aid 
managers to comprehend how to enhance employee organizational learning, knowledge management, organizational innovation, and organizational performance [19]. The positive effect of responsible leadership and organizational inclusion affective, continuance, and normative commitment [20]. How leadership affects work engagement [21]. In this era of intense competition and globalization, organizations are increasingly relying on integrated enterprise systems [22].

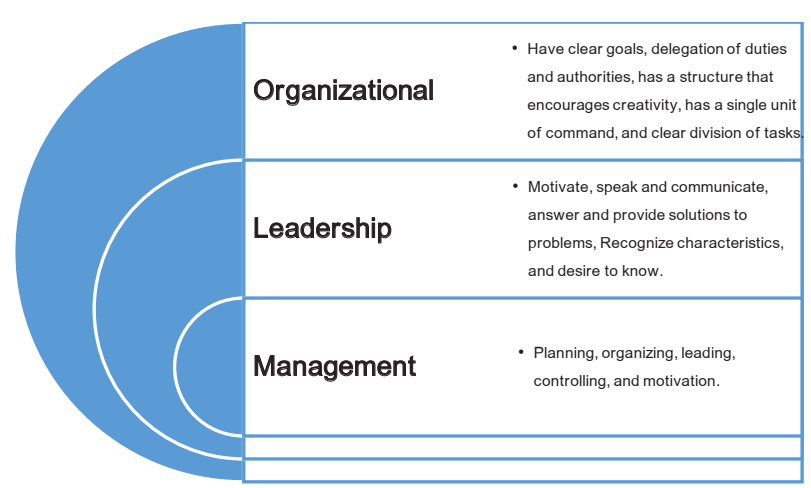

Figure 1. Organizational leadership management basics

Based on this description, organizational leadership management is a human activity carried out jointly led by someone as a manager in a container (association) that directs its members to achieve structured, directed, and shared desires.

\section{CONCLUSION}

Organizational leadership management is carried out in the student association program in the Pancasila and citizenship education study program as a means of provisioning and development to shape the individual character of the younger generation as a national asset and the baton of human resource progress through Pancasila values which become the ideology and philosophy of life of the unitary state of the Republic of Indonesia in order to create an advanced and competitive nation, this characterizes the national identity of the Indonesian nation for every individual who always implements it in his daily life. Thus, the need for training and practice for students in organizational leadership management, in addition to the knowledge obtained, the formation of individual characters based on the values of Pancasila is also necessary.

\section{REFERENCES}

[1] F. Wajdi, "Manajemen Perkembangan Siswa SD Melalui Peran Guru Dan Orang Tua Pada Masa Pandemi," JAMP J. Adminitrasi dan Manaj. Pendidik., vol. 4, no. 1, pp. 41-50, 2021, [Online]. Available: http://journal2.um.ac.id/index.php/jamp/article/ view/17229.
[2] E. Saepudin, K. Suryadi, and E. Malihah, "Youth Pioneering in Sustainable Development," Atl. Press Adv. Soc. Sci. Educ. Humanit. Res., vol. 251, no. Acec, pp. 422-426, 2018, doi: 10.2991/acec-18.2018.96.

[3] C. Astriani and S. Samsuri, "Budi Pekerti Education according to the thought of Ki Hadjar Dewantara as an Effort to Prepare Young Citizens," Atl. Press Adv. Soc. Sci. Educ. Humanit. Res., vol. 251, no. Acec, pp. 379-381, 2018, doi: 10.2991/acec-18.2018.86.

[4] A. P. Belladonna and E. Rohmat, "Studies on Indigenous Ceremony Values in Strengthening the Character of the Nation," Atl. Press Adv. Soc. Sci. Educ. Humanit. Res., vol. 251, no. Acec, pp. 433-440, 2018, doi: 10.2991/acec-18.2018.99.

[5] A. Rosyada and E. D. AR, "Fostering the Attitude of Nationalism Through Hizbul Wathan as the Extracurricular to Build Students Character," Atl. Press Adv. Soc. Sci. Educ. Humanit. Res., vol. 251, no. Acec, pp. 427-429, 2018, doi: 10.2991/acec-18.2018.97.

[6] Z. Wajdi, Farid; Putra, "Penguatan Pendidikan Karakter Melalui Nilai Kearifan Lokal Etnis Bajo dalam Satuan Pendidikan.," in Prosiding Simposium Nasional Filsafat Nusantara Ke-1 (Eksplorasi Kekayaan Filsafat dan Kearifan Lokal Nusantara dalam Rangka Mewujudkan Indonesia Maju), H. Santoso, Ed. Yogyakarta: Laboratorium Filsafat Nusantara Universitas Gadjah Mada, 2020, pp. 63-77.

[7] S. P. Robbins, "Perilaku Organisasi Buku 1, terj," Jakarta: Salemba Empat, 2007.

[8] A. Lestari, "Pengaruh Kepemimpinan Partisipatif Dan Komitmen Organisasi Terhadap Efektifitas Implementasi Rencana Stratejik Pada Madrasah Aliyah Di Kabupaten Sukabumi Jawa Barat," J. Adm. Pendidik. UPI, vol. 23, no. 1, pp. 114-129, 2016, doi: 10.17509/jap.v23i1.5580.

[9] P. G. Northouse, Leadership: Theory and practice. SAGE Publications, Incorporated., 2021.

[10] Syamsuddin, "Penerapan Fungsi-Fungsi Manajemen Dalam Meningkatkan Mutu Pendidikan," Idaarah J. Manaj. Pendidik., vol. 1, no. 1, pp. 3-4, 2017, doi: 10.24252/idaarah.v1i1.4084.

[11] A. Ambarwati, Perilaku Dan Teori Organisasi. Malang: Media Nusa Creative, 2018.

[12] U. Chotimah, A. Alfiandra, E. El Faisal, S. Sulkipani, and C. Camellia, "The Existence of Local Wisdom Values of South Sumatra Community in Strengthening National Integration," Atl. Press Adv. Soc. Sci. Educ. Humanit. Res., vol. 251, no. Acec, pp. 209-212, 2018, doi: 10.2991/acec-18.2018.49. 
[13] J. Biringan and T. D. Wua, "Development of Civic Education in the Modernization Era and Globalization," Atl. Press Adv. Soc. Sci. Educ. Humanit. Res., vol. 251, no. Acec, pp. 183-185, 2018, doi: 10.2991/acec-18.2018.44.

[14] C. Cuga, "Civic Education as Vehicle of Multicultural Education in Building Democratic Citizen," Atl. Press Adv. Soc. Sci. Educ. Humanit. Res., vol. 251, no. Acec, pp. 160-167, 2018, doi: 10.2991/acec-18.2018.40.

[15] F. Putra, Zulfikar; Wajdi, "Implementation of Leadership Values in Pancasila Paradigm as Character Building Values," Soc. Humanit. Educ. Stud. Conf. Ser., vol. 4, no. 4, pp. 45-52, 2021, https://doi.org/10.20961/shes.v4i4.50584.

[16] Sisdiknas, "Undang-Undang Republik Indonesia Nomor 20 Tahun 2003 Tentang Sistem Pendidikan Nasional.," pp. 1-21, 2003, [Online]. Available: www.hukumonline.com.

[17] F. Wajdi, E. Wahyono, and A. Arif, "Management of Student Development on The Impact of Smartphones Through the Role of Parents During the Pandemic," J. Educ. Sci. Technol., vol. 7, no. 2, pp. 155-162, 2021, doi: 10.26858/est.v7i2.19361.

[18] R. Machfiroh, S. Sapriya, and K. Komalasari, "Characteristics of Young Indonesian Citizenship in the Digital Era," Atl. Press $A d v$. Soc. Sci. Educ. Humanit. Res., vol. 251, no. Acec, pp. 5-7, 2018, doi: 10.2991/acec18.2018.2.

[19] A. Noruzy, V. M. Dalfard, B. Azhdari, S. NazariShirkouhi, and A. Rezazadeh, "Relations between transformational leadership, organizational learning, knowledge management, organizational innovation, and organizational performance: An empirical investigation of manufacturing firms," Int. J. Adv. Manuf. Technol., vol. 64, no. 5-8, pp. 10731085, 2013, doi: 10.1007/s00170-012-4038-y.

[20] M. Mousa and V. Puhakka, "Inspiring organizational commitment: Responsible leadership and organizational inclusion in the Egyptian health care sector," J. Manag. Dev., vol. 38, no. 3, pp. 208-224, 2019, doi: 10.1108/JMD-11-2018-0338.

[21] R. J. Blomme, B. Kodden, and A. BeasleySuffolk, "Leadership theories and the concept of work engagement: Creating a conceptual framework for management implications and research," J. Manag. Organ., vol. 21, no. 2, pp. 125-144, 2015, doi: 10.1017/jmo.2014.71.

[22] Z. Shao, Y. Feng, and Q. Hu, "Impact of top management leadership styles on ERP assimilation and the role of organizational learning," Inf. Manag., vol. 54, no. 7, pp. 902919, 2017, doi: 10.1016/j.im.2017.01.005. 